\title{
Vegetation of the Hantam-Tanqua-Roggeveld subregion, SOUTH Africa. Part 1: Fynbos Biome Related Vegetation
}

\author{
HELGA VAN DER MERWE \\ MARGARETHA W. VAN ROOYEN \\ NOEL VAN ROOYEN \\ Department of Plant Science \\ University of Pretoria \\ South Africa
}

Correspondence to: Helga van der Merwe

e-mail: soekop@hantam.co.za

Postal Address: Department of Plant Science, University of Pretoria, Pretoria, 0002

\begin{abstract}
The Succulent Karoo Hotspot stretches along the western side of the Republic of South Africa and Namibia. A lack of botanical information on the Hantam-Tanqua-Roggeveld area of the Succulent Karoo Hotspot was identified during the SKEP (Succulent Karoo Ecosystem Plan) process. A grant from CEPF (Critical Ecosystem Partnership Fund) funded a study to produce a vegetation map of the area to serve as baseline for ecosystem management.

Vegetation surveys were conducted over an area of more than three million hectares from August to October 2004. Two major floristic units were identified, namely the Fynbos Biome related (Mountain Renosterveld) and Succulent Karoo Biome related units. An analysis of the floristic data of the predominantly Mountain Renosterveld vegetation unit is presented in this paper. Three associations were identified, which were subdivided into nine subassociations, one of which contains four variants. The vegetation units are described in terms of their species composition and their relationships with the physical environment. A vegetation map is provided depicting the geographical distribution of the different vegetation types. The main threat to the vegetation of the region identified by the farming community was a lack of infrastructure.
\end{abstract}

Keywords: Mountain Renosterveld, phytosociology, Succulent Karoo, vegetation classification, vegetation map

The Succulent Karoo, which stretches along the western side of South Africa and Namibia, is recognised by the IUCN as one of the global hotspots of biodiversity (Myers et al. 2000, CEPF 2003) and one of only two hotspots that are entirely arid (Conservation International - website).

In 2002 the Succulent Karoo Ecosystem Plan (SKEP) was launched to identify and generate consensus for a 20-year conservation and sustainable land-use strategy for the Succulent Karoo Hotspot. SKEP aims to meet the quantitative targets for the conservation of vegetation and globally threatened and endemic species at particular sites, as well as critical ecological and evolutionary processes that must be conserved to ensure the persistence of these species (Conservation International - website)

For management purposes, the SKEP initiative subdivided the Succulent Karoo into four subregions, of which the HantamTanqua-Roggeveld constituted one. In common with the rest of the Succulent Karoo, the vegetation of the Hantam-TanquaRoggeveld subregion includes a wide range of succulents, geophytes and annuals. After good rains, the spectacular autumn and spring displays of wild flowers in parts of the region attract large numbers of tourists. Unlike many parts of Namaqualand, such brilliant shows of annuals and geophytes are not only a feature of fallow fields, but also occur in the undisturbed natural vegetation in the Hantam and Roggeveld (Van Wyk \& Smith 2001).

The identification, description and classification of vegetation units across the landscape comprise the critical first steps in building a framework for ecosystem management planning.
Information on the spatial, temporal and ecological properties of the vegetation units can lead to the improved understanding, protection and management of natural resources. Progression of the SKEP initiative soon showed the paucity of data available on the biodiversity of the Hantam-Tanqua-Roggeveld subregion, which was key to future planning, conservation and development. The Critical Ecosystem Partnership Fund (CEPF), which is a joint initiative of Conservation International, the Global Environmental Facility, the Government of Japan, the MacArthur Foundation and the World Bank, therefore granted funding for botanical studies in the subregion.

The first step of the botanical study was to undertake a systematic broad-scale vegetation survey of the entire subregion of approximately three million hectares, which could be used as the basis for further detailed botanical investigations. The survey revealed two distinct vegetation groups, i.e. the Fynbos Biome related Mountain Renosterveld vegetation group and the Succulent Karoo Biome related vegetation group. The aim of the present article is to report on the Mountain Renosterveld vegetation, depicting its component vegetation units on a map. A second article (Van der Merwe et al. in press) will report on the latter vegetation group.

\section{STUDY AREA}

The Hantam-Tanqua-Roggeveld subregion (Fig. 1), as defined in thecurrentstudy, lies in the predominantly winter rainfall region of the Northern and Western Cape Provinces of South Africa, and covers an area of approximately three million hectares. In the west it stretches from east of the Cederberg Mountains 
in the southwestern corner, northwards along the Bokkeveld Mountains to just north of Loeriesfontein. The eastern border includes the Roggeveld and Nuweveld Mountain Ranges to just southwest of Fraserburg, while the southern limit includes the Tanqua and Ceres Karoo to where the Swartrug Mountains and the Bontberg Mountains meet north of Ceres.

The Mountain Renosterveld discussed in the current article is found on the Roggeveld, Nuweveld, Komsberg, Klein Roggeveld, Koedoesberg and Hantam Mountains. In general, this is the higher-lying part of the larger subregion that is actually situated in the Fynbos Biome (Rutherford \& Westfall 1986). This area includes Acocks's (1988) Mountain Renosterveld (Veld Type 43), which is equivalent to the Escarpment Mountain Renosterveld (Unit 60) of Low and Rebelo (1998). According to Mucina et al. (2005), six vegetation types are represented in the area, namely the Nieuwoudtville Shale Renosterveld (FRs 2); the Roggeveld Shale Renosterveld (FRs 3); the Central Mountain Shale Renosterveld (FRs 5); the Nieuwoudtville Roggeveld Dolerite Renosterveld (FRd 1); the Hantam Plateau Dolerite Renosterveld (FRd 2); and the Roggeveld Karoo (SKt 3).

The earliest references to the botanical wealth of the HantamRoggeveld date from the early 1900s. Diels (1909 in Van Wyk \& Smith 2001) mentioned the high levels of endemism in the Hantam-Roggeveld and provided a useful floristic analysis of the region. He concurred with Marloth (1908) that the region is floristically more closely related to the Succulent Karoo and the Great Karoo than to the Cape Floristic Region, although Cape floristic elements are clearly present, especially on the Hantamsberg (Van Wyk \& Smith 2001). The Roggeveld was also one of the three centres of endemism that Hilton-Taylor (1994) identified within the Western Cape Domain, the other two centres being the Western Mountain Karoo and Tanqua Karoo, which also fall within the Hantam-Tanqua-Roggeveld subregion. Van Wyk and Smith (2001) combined the HantamRoggeveld into one of their 13 principal centres of plant endemism in southern Africa and stressed the unique botanical importance of this area.

The rainfall ranges from 132-467 mm per year (Weather Bureau 1998), which, although falling mainly in winter, includes a few summer thunderstorms. In 2004 the rainfall season was poor and the usual winter snowfalls on the high-lying areas were limited to the light snow that fell on one occasion, compared with the mean of six snow days recorded over a 24-year period by the Weather Bureau (1998). At Sutherland the mean maximum for the warmest month, January, is $27.1^{\circ} \mathrm{C}$, while, the extreme maximum recorded was $35.5^{\circ} \mathrm{C}$ in January 1980 (Weather Bureau 1998). The mean minimum for the coldest month, July, is $-2.4^{\circ} \mathrm{C}$, while the extreme minimum, $-13.6^{\circ} \mathrm{C}$, was recorded in July 1970 and August 1978 (Weather Bureau 1998).

Rocks of the Ecca Group cover most of this area with Dwyka (consisting of tillite, sandstone, mudstone and shale) cropping out in the west and the Beaufort Group in the east (Council for Geoscience 1973, 1983, 1989, 1991, 1997, 2001). The Ecca Group includes sediments of the Koedoesberg Formation (consisting of sandstone and shale) and the Tierberg Formation (consisting of shale) (Council for Geoscience 1973, 1983, 1989, 1991, 1997, 2001). Mudstones of the Beaufort Group are found on the eastern side of the study area (Council for Geoscience 1973, 1983, 1989, 1991, 1997, 2001). Igneous intrusions of dolerite occur throughout the region, being easily recognisable as very hard, dark grey to nearly black rocks (Van Wyk \& Smith 2001). The soils of the Roggeveld consist primarily of clays and silts derived from the Karoo sequence shales (Low \& Rebelo 1998) and are found on the slopes and foothills of the Great Escarpment along the various mountain ranges.

\section{METHODS AND MATERIALS}

Satellite images (Bands: 4, 5 and $3(\mathrm{R}, \mathrm{G}, \mathrm{B}))$ of the study area were visually stratified into relatively homogeneous units on the basis of colour, texture and topography. This stratification was used to select the sites at which sample plots were surveyed from August until October 2004. At each site GPS (Global Positioning System) coordinates were taken and each species present in the plot was noted and assigned a cover-abundance value according to the Braun Blanquet cover-abundance scale (Werger 1974). Various environmental characteristics, such as altitude, topography, aspect, slope, an estimation of rock cover, the size of the rocks, soil type and colour, and the degree of erosion were noted at each sampling point. Biotic effects, such as trampling, small mammal activity, or invasion by alien plants, were also recorded.

A total of 390 sample plots covering the entire Hantam-TanquaRoggeveld subregion were surveyed in 2004. An analysis of the floristic data was undertaken using the TURBOVEG and MEGATAB computer package (Hennekens \& Schaminée 2001). Vegetation data were captured with the TURBOVEG software and the data were classified with the aid of MEGATAB.

As a first step to the classification of the floristic data, a Two-Way Indicator Species Analysis (TWINSPAN) (Hill 1979) was run in MEGATAB. The result of the TWINSPAN on the entire data set confirmed the presence of two distinct floristic groups, which enabled the data set to be split into two. A TWINSPAN was then run separately on each data set, with the resulting tables being further refined to obtain clear species assemblages. The first phytosociological table, which characterises the vegetation of the predominately Mountain Renosterveld as defined by Acocks (1988), is discussed in the current article.

The major vegetation units distinguished in the Mountain Renosterveld were termed associations following the use as defined by Nelder et al. (2005). Associations are produced on the basis of the presence and abundance of species, vegetation structure and the spatial distribution of individuals in the dominant layer. Subassociations are generally distinguished on the basis of elements in the subdominant layers. The subassociations are described in terms of a list of species featuring each structural layer, together with its canopy cover. 


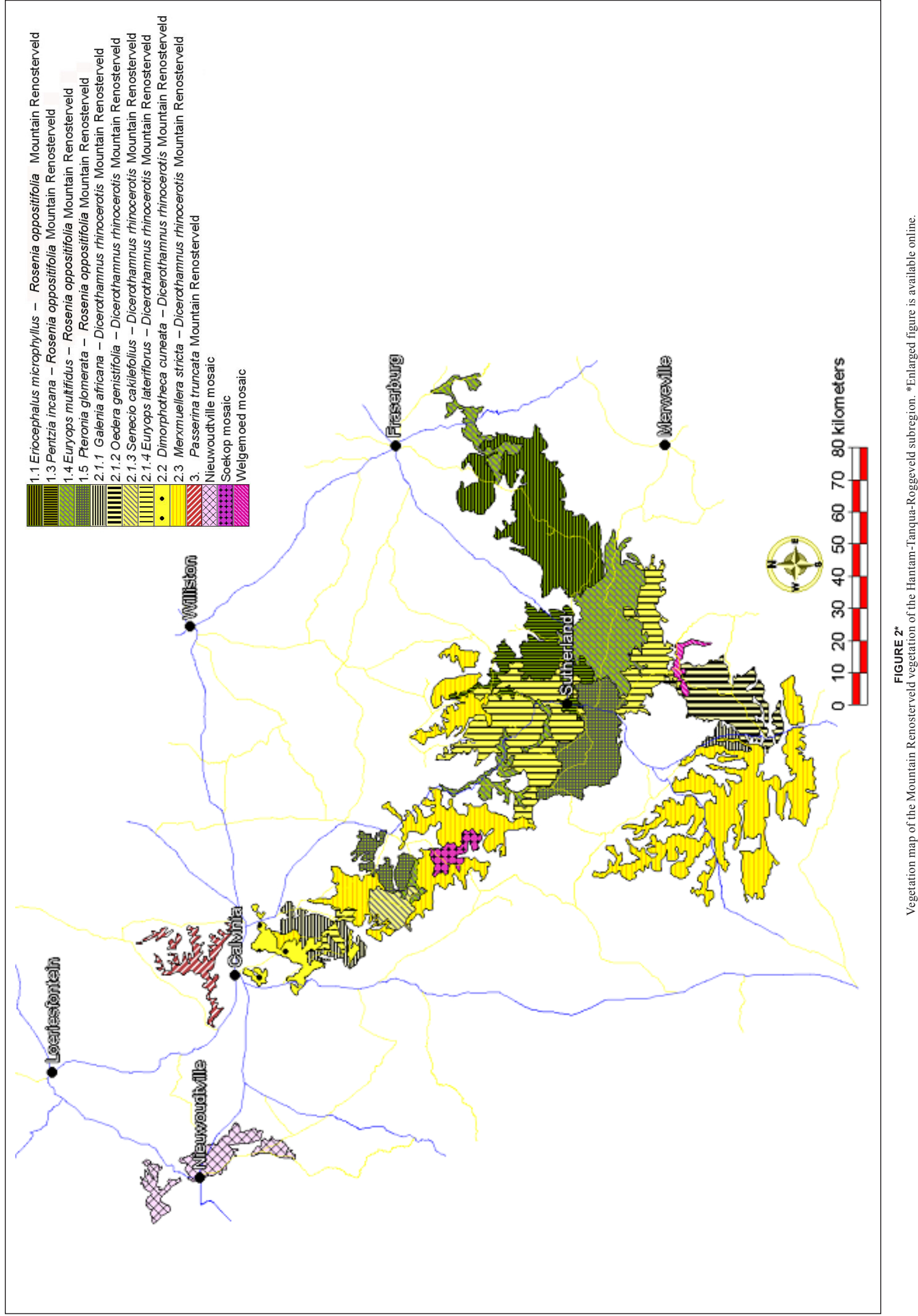




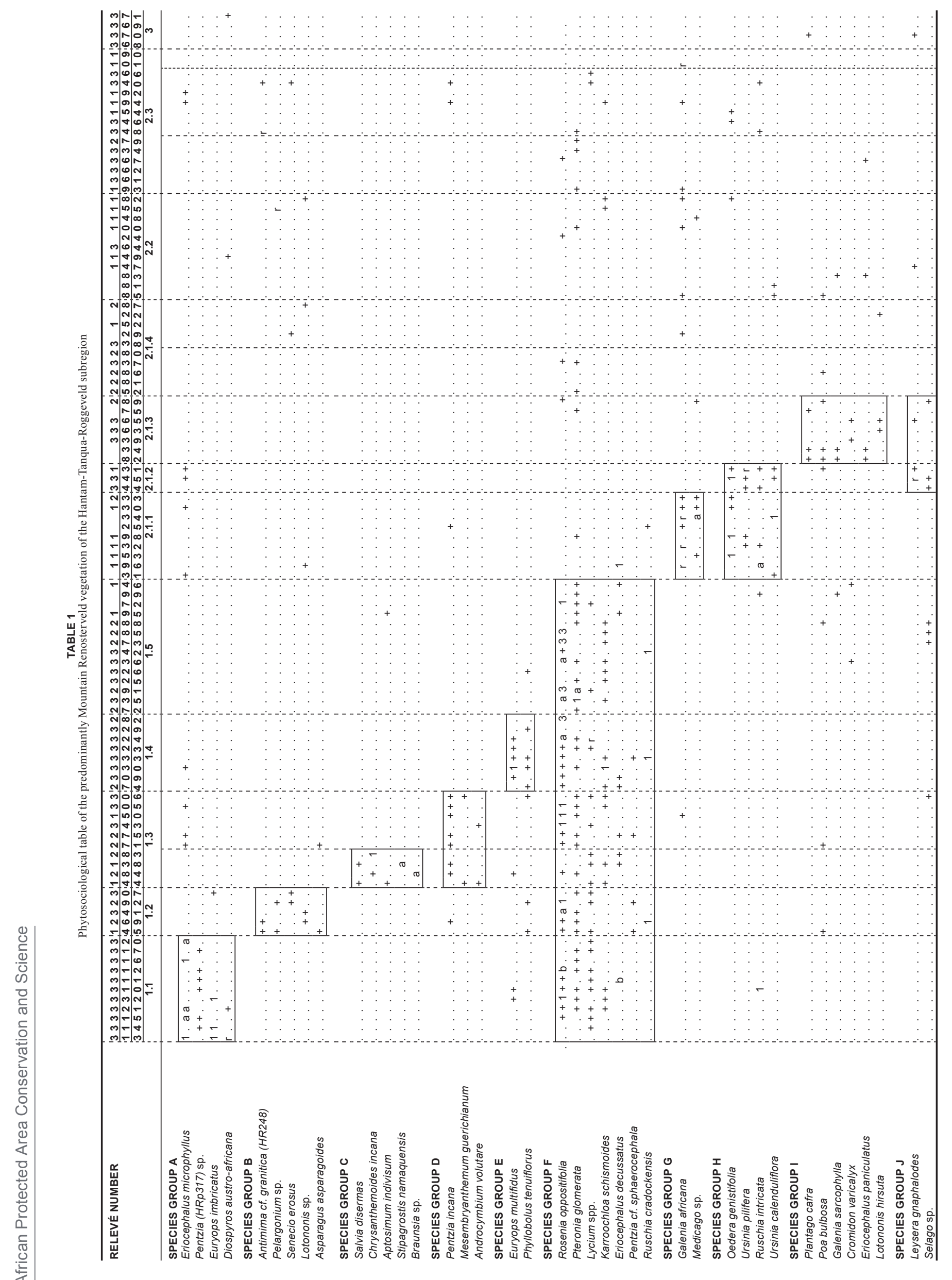




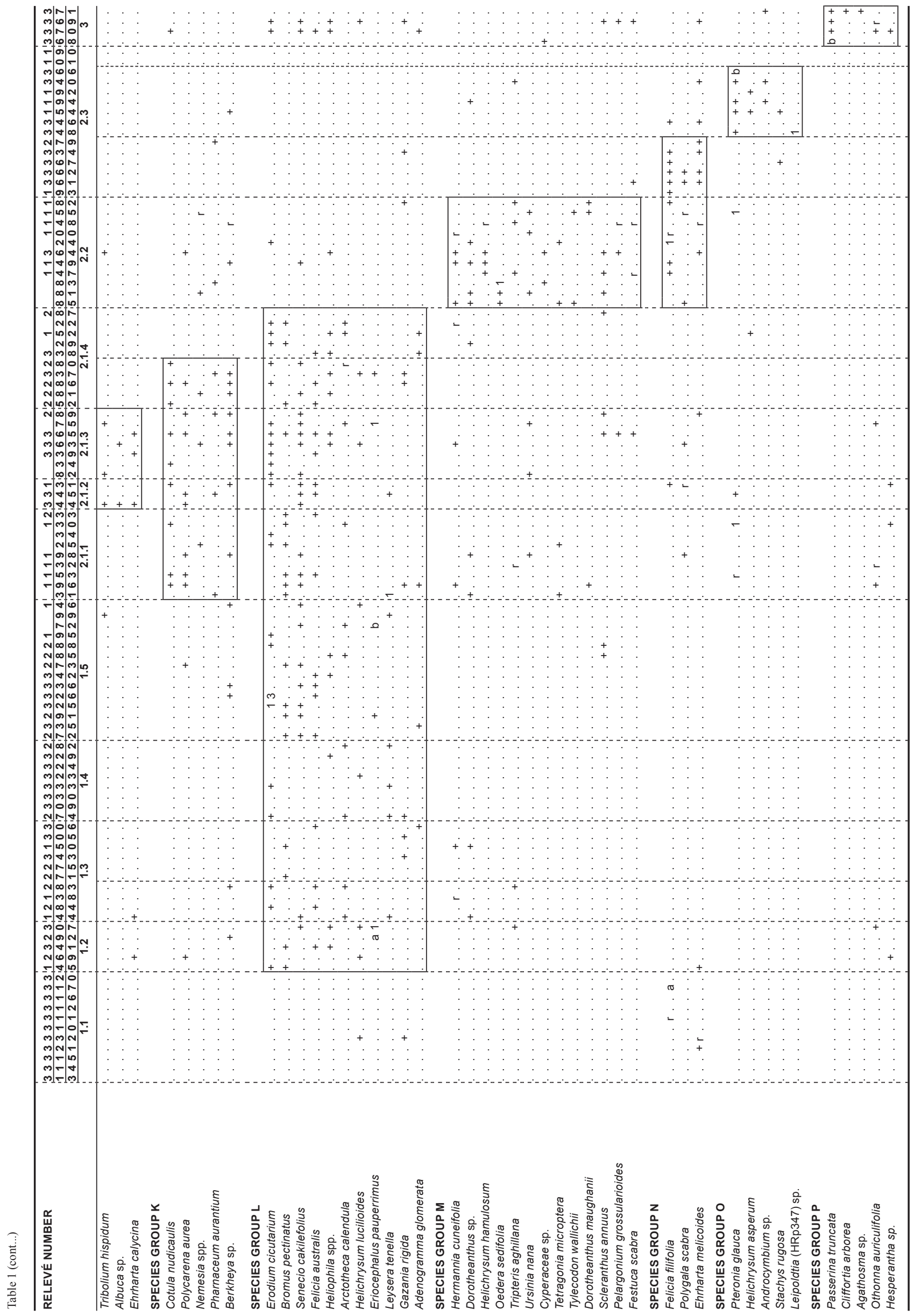




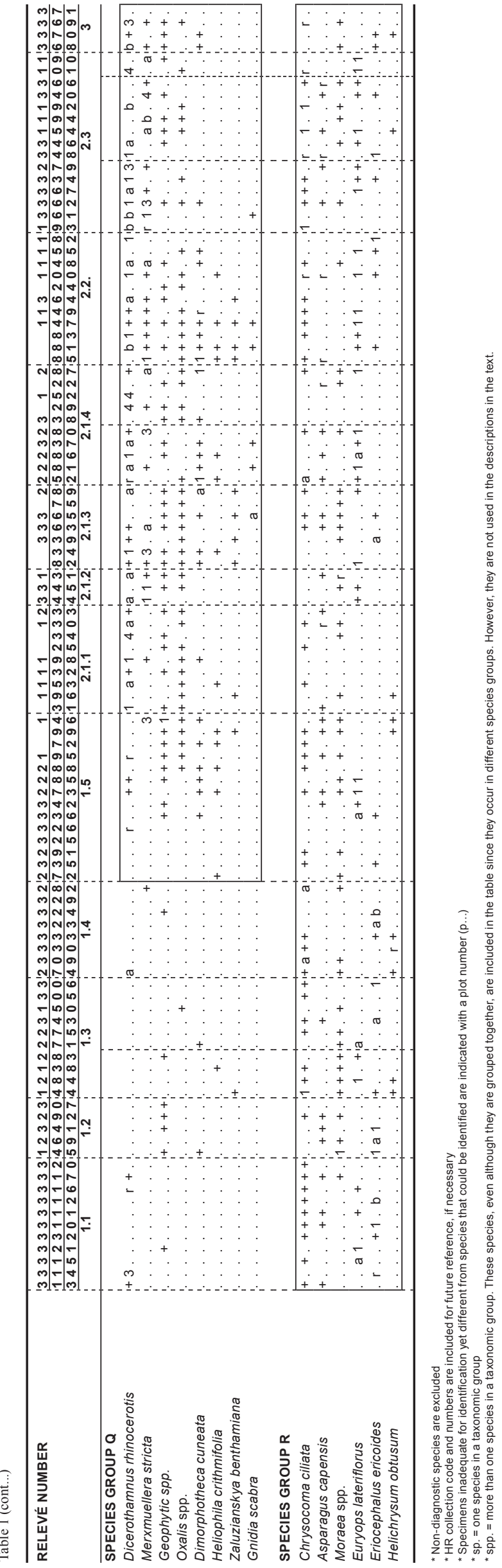

Using the distribution of the sample plots, supported by 1:250 000 topocadastral maps, land type maps (Agricultural Research Council 1986a, 1986b, 1995, 1999a, 1999b, 2002, 2003), geology maps (Council for Geoscience 1973, 1983, 1989, 1991, 1997, 2001) and satellite images, the stratified units were assigned to a vegetation unit in the floristic classification. Where two or more subassociations were present in a mapping unit, but it was not possible to map them separately as a result of high spatial diversity, they were mapped as mosaics of specific vegetation types.

Species that were unidentifiable during the field surveys were collected and the herbarium specimens sent to the Compton Herbarium, Kirstenbosch, for identification. The collection code (HR) and numbers of the specimens were kept throughout the process as not all the species, especially within the Mesembryanthemaceae, have yet been positively identified. All voucher specimens are lodged at the Schweickerdt Herbarium (PRU), University of Pretoria, Pretoria. Nomenclature follows that of Germishuizen and Meyer (2003).

\section{RESULTS}

The floristic data analysis resulted in two phytosociological tables. The first table (Table 1) contains the predominantly Mountain Renosterveld veld type, as defined by Acocks (1988), or the Escarpment Mountain Renosterveld vegetation type, as defined by Low and Rebelo (1998), and is described in this article. Three associations were identified, which were subdivided into nine subassociations, one of which contains four variants, as set out in the following scheme:

1. Rosenia oppositifolia Mountain Renosterveld

1.1 Eriocephalus microphyllus - Rosenia oppositifolia Mountain Renosterveld

1.2 Antimima cf. granitica (HR248) - Rosenia oppositifolia Mountain Renosterveld

1.3 Pentzia incana - Rosenia oppositifolia Mountain Renosterveld

1.4 Euryops multifidus - Rosenia oppositifolia Mountain Renosterveld

1.5 Pteronia glomerata - Rosenia oppositifolia Mountain Renosterveld

2. Dicerothamnus rhinocerotis Mountain Renosterveld

2.1 Erodium cicutarium - Dicerothamnus rhinocerotis Mountain Renosterveld

2.1.1 Galenia africana-Dicerothamnus rhinocerotis Mountain Renosterveld

2.1.2 Oedera genistifolia-Dicerothamnus rhinocerotis Mountain Renosterveld

2.1.3 Senecio cakilefolius - Dicerothamnus rhinocerotis Mountain Renosterveld

2.1.4 Euryops lateriflorus - Dicerothamnus rhinocerotis Mountain Renosterveld

2.2 Dimorphotheca cuneata - Dicerothamnus rhinocerotis Mountain Renosterveld

2.3 Merxmuellera stricta - Dicerothamnus rhinocerotis Mountain Renosterveld

3. Passerina truncata Mountain Renosterveld

With the exception of unit 1.2, all vegetation units could be mapped (Fig. 2). Three additional mosaics were also mapped:

- the Nieuwoudtville mosaic, consisting of vegetation units 2.1.1, 2.1.4, 2.2 and 5.1 (Van der Merwe et al. in press);

- the Soekop mosaic, consisting of units 2.1.3 and 2.2; and the

- Welgemoed mosaic, consisting of units 1.2, 1.3 and 1.5.

A large number of different land types are found in the study area and therefore only the predominant types are listed for each vegetation unit (Agricultural Research Council 1986a 1986b, 1995, 1999a, 1999b, 2002, 2003). Table 2 summarises the most important features of the various land type symbols that have been used in the text. 


\section{Description of plant communities (Table 1, Fig. 2)}

The 2004 winter season was extremely dry, resulting in annuals and geophytes being poorly represented in the survey. The following description will therefore focus on the perennial plant species with permanent above-ground organs.

\section{Rosenia oppositifolia Mountain Renosterveld}

This plant association is located at the southern end of the Roggeveld and Nuweveld Mountains as well as in the vicinity of the farms Onderplaas and Droëkloof further north and occurs predominantly on Land Types Fc and Da. Mudstones of the Beaufort Group as well as dolerites are found underlying this association. The association is generally found on level terrain, gentle or moderate sloping ridges with a low rock cover from 0 to $10 \%$ or a high rock cover of 70 to $90 \%$. Brown or light brown sandy soils are prevalent in this high-lying plant association. Although a high shrub cover is present, the grass and annual component only sometimes feature, usually with less than $5 \%$ cover.

The vegetation of this association is characterised by species group F with a high cover of Rosenia oppositifolia and includes species such as Pteronia glomerata and Karroochloa schismoides. Common species include Chrysocoma ciliata, Euryops lateriflorus and Eriocephalus ericoides (species group R). This association has been subdivided into five subassociations.

\subsection{Eriocephalus microphyllus - Rosenia oppositifolia Mountain Renosterveld}

This unit is found in the region of the Nuweveld Mountains and covers an area of 106454 ha (13.2\% of the total area covered by Mountain Renosterveld vegetation). Geologically, this subassociation is found on mudstones of the Beaufort Group and predominantly on Land Type $\mathrm{Fc}_{\mathrm{c}}$, indicating that there is lime present in the entire landscape. This high-lying vegetation occurs at an altitude of $>1400 \mathrm{~m}$ above sea level on ridges with level terraces to gentle slopes. The rock cover varies from zero to $>85 \%$, and is usually comprised of stones $(>50-200 \mathrm{~mm})$ and boulders (> $200 \mathrm{~mm}$ ).

Shrub cover is generally high (mean cover 66\%) and is characterised by species such as Rosenia oppositifolia and Pteronia glomerata (species group F) as well as the diagnostic species Eriocephalus microphyllus, Pentzia sp. (HRp317) and Euryops imbricatus (species group A). Other shrubs also present include Chrysocoma ciliata, Euryops lateriflorus and Eriocephalus ericoides of species group R. Grasses are either absent or their cover is limited to less than 5\%, while annuals are seldom present. This phenomenon could, however, be a result of the drought conditions experienced during the time in which the surveys were conducted.

\subsection{Antimima cf. granitica (HR248) - Rosenia oppositifolia Mountain Renosterveld}

Dolerite-derived B horizon soils on Land Types Da and Fc characterise this subassociation that is scattered throughout the Roggeveld Mountains and has not been mapped as a separate unit. The altitude generally ranges from 1200 to $1350 \mathrm{~m}$ above sea level. The high-lying ridges with level terrain to moderate slopes on brown to red brown sandy soils are usually covered with stones (> 50-200 $\mathrm{mm}$ in size). Shrub cover in this unit is high (with a mean value of $72 \%$ ), while the herbaceous component is generally $<5 \%$. Almost no grasses contribute to the herbaceous cover.

The shrub layer is characterised by species such as Rosenia oppositifolia, Pteronia glomerata (species group F), Eriocephalus pauperrimus (species group L) as well as Asparagus capensis and Eriocephalus ericoides (species group R). Diagnostic perennial species include Antimima cf. granitica (HR248) and Pelargonium sp. (species group B).
TABLE 2

Land type symbols and their meaning within the text (Du Plessis 1987)

\begin{tabular}{cl}
\hline LAND TYPE & MEANING OF SYMBOL \\
\hline D & $\begin{array}{l}\text { Prismacutanic and/or pedocutanic diagnostic horizons dominate. } \\
\text { After subtracting exposed rock, stones or boulders, more than half } \\
\text { of the remaining land must consist of duplex soils. }\end{array}$ \\
Da $\quad \begin{array}{l}\text { Refers to land where duplex soils with red B horizons comprise } \\
\text { more than half of the area covered by duplex soils. }\end{array}$ \\
Db $\quad \begin{array}{l}\text { Refers to land where duplex soils with non-red B horizons } \\
\text { comprise more than half of the area covered by duplex soils. }\end{array}$ \\
$\mathrm{F} \quad \begin{array}{l}\text { Glenrosa and/or Mispah forms (though other soils may occur). The } \\
\text { group accommodates pedologically young landscapes that are not } \\
\text { predominantly rock, alluvial or aeolian and in which the dominant }\end{array}$ \\
soil-forming processes have been rock weathering, the formation \\
of orthic topsoil horizons and clay illuviation.
\end{tabular}

1.3 Pentzia incana - Rosenia oppositifolia Mountain Renosterveld

Subassociation 1.3 is located around Sutherland and east of Sutherland on mudstones of the Beaufort Group. It also occurs further south in combination with subassociations 1.2 and 1.5 in the vicinity of the farm Welgemoed, at the foot of the Komsberg Mountains. This subassociation, excluding the mosaic unit, covers an area of 44499 ha (5.5\% of the total area covered by Mountain Renosterveld vegetation). Land types include Fc and Da and altitude ranges from approximately 1300-1500 m above sea level. The high-lying ridges on level terrain to moderate slopes are usually covered with brown or light brown sandy soils.

The high shrub cover is attributed to species such as Pentzia incana (species group D), Rosenia oppositifolia and Pteronia glomerata (species group F) as well as Chrysocoma ciliata and Euryops lateriflorus (species group R). This subassociation shows local variations resulting from a low constancy of such species as Stipagrostis namaquensis, Braunsia sp. and Chrysanthemoides incana (species group $\mathrm{C}$ ). When the perennial shrub cover is high, species in group $\mathrm{C}$ do not occur, however, when the shrub cover is lower, species in group C can dominate. Generally, the cover of the grass and non-grassy herbaceous layer is limited, except in the case of the grass species Stipagrostis namaquensis that occurred in a single relevé sampled in a drainage line.

\subsection{Euryops multifidus - Rosenia oppositifolia Mountain} Renosterveld

Located just north of the Komsberg, subassociation 1.4 is found predominantly on mudstones of the Beaufort Group and covers an area of 106189 ha $(13.1 \%$ of the total area covered by Mountain Renosterveld vegetation). Land types present include $F_{C}$ and $\mathrm{Da}$, with, occasionally, deep deposits of the Ia land type. This subassociation is found at an altitude of between 1400-1500 m above sea level. The level to gently sloped ridges and light brown soils in this subassociation support a high shrub canopy cover of between 60 and $90 \%$.

The diagnostic species Euryops multifidus and Phyllobolus tenuiflorus (species group E), together with Rosenia oppositifolia (species group F), Chrysocoma ciliata and Eriocephalus ericoides (species group R) characterise this subassociation. The cover of the herbaceous component (including grasses) is usually limited 
to $<5 \%$, which could be the result of the drought conditions in the year of survey.

\subsection{Pteronia glomerata - Rosenia oppositifolia Mountain} Renosterveld

Geologically, this subassociation occurs predominantly on mudstones of the Beaufort Group and is similar to subassociations 1.3 and 1.4. It is found on Land Types Fc, Da and $\mathrm{Db}$ on the southwestern extreme of the Roggeveld Mountains. It also occurs in a mosaic with subassociations 1.2 and 1.3 in the vicinity of the farm Welgemoed at the foot of the Komsberg Mountains. This subassociation covers an area of 69233 ha ( $8.6 \%$ of the total area of the Mountain Renosterveld vegetation), excluding the mosaic unit. This high-lying (1200-1600m above sea level) subassociation is found on level terrain and gentle slopes on a range of different rock sizes, varying from gravel $(<10 \mathrm{~mm})$ to boulders $(>200 \mathrm{~mm})$. The soil colour also varies substantially from light brown to brown to red brown.

Shrub cover is generally high ( $>60 \%$ ) and the grassy component has a higher presence and cover compared with the previous subassociations. Likewise, annual species are present in all relevés, with their cover generally being higher than in the previous subassociations. This was probably the case due to the local rain showers received in the area during the year of survey.

No diagnostic species group separates this subassociation. The most prominent species present include Rosenia oppositifolia, Pteronia glomerata (species group F), Erodium cicutarium (species group L) and Euryops lateriflorus (species group R). The grass component is represented by Karroochloa schismoides (species group F) and Bromus pectinatus (species group L) with, in one relevé, a high cover of Merxmuellera stricta (species group Q). Erodium cicutarium and Felicia australis (species group L) as well as Heliophila crithmifolia (species group Q) represent some of the annual species.

\section{Dicerothamnus rhinocerotis Mountain Renosterveld}

This plant association is located in the Roggeveld, Klein Roggeveld, Koedoesberg and Komsberg Mountains and has been further subdivided into three subassociations. Generally it can be found on the mudstones of the Beaufort Group or the shales of the Ecca Group on Land Types $\mathrm{Da}, \mathrm{Fb}, \mathrm{Fc}$, Ib and Fa. The level terrain and gentle slopes of subassociations 2.1 and 2.2 as well as the gentle to moderate slopes of subassociation 2.3 are usually comprised of light brown or brown sandy soils. The shrub cover is high (50-95\%) and a grass and annual component are generally present throughout the association. The very high cover of Dicerothamnus rhinocerotis, Merxmuellera stricta and Dimorphotheca cuneata (species group Q) distinguishes this association from the Rosenia oppositifolia Mountain Renosterveld (association 1).

\subsection{Erodium cicutarium - Dicerothamnus rhinocerotis Mountain Renosterveld}

Subassociation 2.1 generally occurs on mudstones of the Beaufort Group in the Roggeveld, Klein Roggeveld and Komsberg Mountains on Land Types $\mathrm{Da}, \mathrm{Fb}, \mathrm{Fc}$ and $\mathrm{Ib}$, and excluding mosaic units, covers an area of 213410 ha $(26.4 \%$ of the total area of Mountain Renosterveld vegetation). The altitude varies from 600 to about $1600 \mathrm{~m}$ above sea level and the landscape is gently undulating. Soils are light brown sandy soils with a varying rock cover consisting predominantly of boulders (> $200 \mathrm{~mm}$ ). The shrub cover is generally high (50-95\%), with grass and other herbaceous species consistently occurring across all the surveyed sites.

Prominent perennial species in this subassociation include Dicerothamnus rhinocerotis, Merxmuellera stricta (species group Q) as well as Euryops lateriflorus (species group R). Common annual species occurring in the unit include Erodium cicutarium, Bromus pectinatus, Senecio cakilefolius and Felicia australis (species group L). This subassociation has been subdivided into four variants.

\subsubsection{Galenia africana - Dicerothamnus rhinocerotis Mountain} Renosterveld

This variant is floristically very diverse and occurs on the mudstones of the Beaufort Group and the shales of the Ecca Group. It is located in the region of the farms $\mathrm{M}^{\prime}$ Vera and Vondelingsfontein at the northern extreme of the Roggeveld Mountains and Kareebos and Rooiwal west of the Klein Roggeveld Mountains. It also forms a mosaic in combination with variant 2.1.4, subassociation 2.2, and subassociation 5.1 (Van der Merwe et al. in press) in the Nieuwoudtville area. Excluding mosaics, this variant covers an area of 25369 ha ( $3.1 \%$ of the total area of the Mountain Renosterveld vegetation). Various land types are present, predominantly of the Da and $\mathrm{Fb}$ types. The altitude is notably lower than for the other vegetation units, and varies from 600 to $1300 \mathrm{~m}$ above sea level. This variant occurs on undulating terrain. The light brown to brown coloured sandy soils are usually not covered by much rock, however, boulders (> $200 \mathrm{~mm}$ ) do occur locally.

A high shrub cover results primarily from the presence of Dicerothamnus rhinocerotis (species group Q) as well as the diagnostic species Galenia africana (species group G). Various annual species, such as Cotula nudicaulis and Polycarena aurea (species group K) and Erodium cicutarium, Senecio cakilefolius, Felicia australis and Leysera tenella (species group L), are present. The annual grass Bromus pectinatus (species group L) contributes to the low cover of the grass component in the variant. The absence of species group $\mathrm{J}$ in this variant differentiates it from variant 2.1.2. The presence of Galenia africana and various annuals indicates the increased disturbance that has taken place in this variant in the past.

\subsubsection{Oedera genistifolia - Dicerothamnus rhinocerotis Mountain Renosterveld}

Variant 2.1.2 occurs on the mudstones of the Beaufort Group in the Klein Roggeveld Mountains, and covers an area of 46797 ha (5.8\% of the total area of the Mountain Renosterveld vegetation). It is found at an altitude between 1000 and $1300 \mathrm{~m}$ above sea level on level terrain to gentle slopes. The light brown sandy soils of this variant are covered with gravel $(<10 \mathrm{~mm})$, small stones $(>10-50 \mathrm{~mm})$ and boulders $(>200 \mathrm{~mm})$, which are typical of Land Type Ib.

The high shrub cover (more than $70 \%$ ) is primarily a result of the presence of Dicerothamnus rhinocerotis (species group Q) as well as Oedera genistifolia (species group $\mathrm{H}$ ) and Euryops lateriflorus (species group R). Merxmuellera stricta (species group Q), a perennial grass, dominates the grass component of this variant. Annual species are consistently present, however, their cover is low due to the drought conditions in the year in which the surveys were conducted.

The presence of species groups $\mathrm{G}$ and J distinguishes variant 2.1.1 from variant 2.1.2, whereas the absence of species group I distinguishes variant 2.1.2 from variant 2.1.3.

\subsubsection{Senecio cakilefolius - Dicerothamnus rhinocerotis Mountain Renosterveld}

This variant, excluding mosaics, covers an area of 13654 ha $(1.7 \%$ of the total area covered by Mountain Renosterveld vegetation) and is found on mudstones of the Beaufort Group and shales of the Ecca Group in the region of the farms Botuin, Blomfontein and De Hoop in the Roggeveld Mountains, predominantly on Land Types Da and Fc. In combination with subassociation 2.2 in the region of the farm Soekop, it is found in a mosaic 
vegetation unit. It occurs at altitudes higher than $1200 \mathrm{~m}$ above sea level on level terrain to gently sloping landscapes with light brown to brown coloured soils. Rocks are mostly absent, although boulders do occasionally occur.

Shrub cover varies considerably, with the main contributors being Dicerothamnus rhinocerotis and Dimorphotheca cuneata (species group Q) as well as Chrysocoma ciliata, Asparagus capensis, Euryops lateriflorus and Eriocephalus ericoides (species group R). The grass component varies considerably depending on the presence or absence of the perennial grass Merxmuellera stricta (species group Q). The most prominent annual species include Cromidon varicalyx and Plantago cafra (species group I), Cotula nudicaulis and Polycarena aurea (species group K) as well as Erodium cicutarium and Senecio cakilefolius (species group L). The cover of this component is highly variable, depending on the amount of rainfall received locally during the season.

Variant 2.1.3 has a close affinity with variant 2.1.2 due to their sharing species group $\mathrm{J}$, however, they differ as a result of the presence of species group I that is confined to variant 2.1.3.

\subsubsection{Euryops lateriflorus - Dicerothamnus rhinocerotis} Mountain Renosterveld

Variant 2.1.4 occurs on Land Types Da and Fc in the Komsberg Mountains and southwest of the Basterberg Mountains and covers an area of 127590 ha $(15.8 \%$ of the total Mountain Renosterveld vegetation), excluding the mosaic vegetation unit. The mosaic is found in combination with variant 2.1.1, subassociation 2.2, and subassociation 5.1 in the Nieuwoudtville area (Van der Merwe et al. in press). This variant is generally found at high altitudes on level terrain to gentle slopes. The light brown soils are derived from mudstones of the Beaufort Group. Rocks are generally absent, although boulders (> $200 \mathrm{~mm}$ ) may occur locally.

The high shrub cover is due primarily to Dicerothamnus rhinocerotis and Dimorphotheca cuneata (species group Q) as well as Chrysocoma ciliata, Asparagus capensis and Euryops lateriflorus (species group R). The grass cover is generally low, except where Merxmuellera stricta (species group Q) dominates. The cover of the annual component is generally low.

Two forms of variant 2.1.4 occur as a result of the presence or absence of species group $\mathrm{K}$, which mainly consists of annual species. Such species might have occurred throughout the region in a normal rainfall year.

\subsection{Dimorphotheca cuneata - Dicerothamnus rhinocerotis Mountain Renosterveld}

This high-lying subassociation can be found in the Keiskie Mountains, at the northern extreme of the Roggeveld Mountains, and excluding mosaics, covers an area of 20196 ha $(2.5 \%$ of the total area covered by Mountain Renosterveld vegetation). It also occurs in combination with variant 2.1.3 in the region of the farm Soekop and additionally, it forms a mosaic in the Nieuwoudtville area in combination with variants 2.1.1 and 2.1.4 and subassociation 5.1 (Van der Merwe et al. in press). The land types present include $\mathrm{Da}, \mathrm{Fa}$ and $\mathrm{Fc}$ and the altitude varies from $700-1400 \mathrm{~m}$ above sea level. The undulating terrain is usually covered by a high percentage of boulders $(>200 \mathrm{~mm})$. The light brown to brown coloured sandy soils are derived from Ecca shales.

The shrub cover varies greatly $(20-80 \%)$, whereas the cover of both the grass and annual species remains low. Diagnostic species include Hermannia cuneifolia, Helichrysum hamulosum and Oedera sedifolia (species group M). Felicia filifolia, Polygala scabra and Ehrharta melicoides (species group N) are common to both subassociation 2.2 and 2.3, although subassociation 2.3 lacks species group M. The dominant species is Dicerothamnus rhinocerotis and other prominent species include Merxmuellera stricta, Dimorphotheca cuneata (species group Q) and Chrysocoma ciliata, Euryops lateriflorus and Eriocephalus ericoides (species group R).

\subsection{Merxmuellera stricta - Dicerothamnus rhinocerotis} Mountain Renosterveld

This subassociation is located in the region of the farms Piet se Nuplaas, Droëberg, Nuwepos, Soekop and Vaalhoek in the Roggeveld Mountains and includes the higher-lying vegetation of the Koedoesberg and Basterberg Mountains. It covers an area of 230838 ha $(28.5 \%$ of the total Mountain Renosterveld vegetation). Geologically, it occurs on the mudstones of the Beaufort Group, the shales of the Ecca Group and even, occasionally, on dolerites occurring within the mudstones and shales. Land types include Fc, Da and occasionally Ib at an altitude of 900 to $1600 \mathrm{~m}$ above sea level. The high-lying gentle to moderately steep slopes are usually covered with stones (> 50-200 mm) or boulders (> $200 \mathrm{~mm}$ ). The soils are generally brown sandy soils. Shrub and grass cover vary considerably, whereas the annual component is either absent or covers less than $1 \%$ of the area.

Three variations are distinguished in this subassociation. The first variation is differentiated by the presence of species group $\mathrm{N}$, which is shared with subassociation 2.2. The second variation is characterised by the perennial shrub Pteronia glauca (species group O), whereas the third variation does not include species group $\mathrm{N}$ or $\mathrm{O}$. In all of these variations Dicerothamnus rhinocerotis, Merxmuellera stricta (species group Q) and Chrysocoma ciliata (species group R) dominate with a very high cover (60-95\%). Other species present include Asparagus capensis, Euryops lateriflorus and Eriocephalus ericoides (species group R).

\section{Passerina truncata Mountain Renosterveld}

The third plant association, which is found exclusively on dolerites on Land Type Ia, occurs at high altitudes (approximately $1500 \mathrm{~m}$ above sea level and higher) on the Hantam Mountain as well as at various locations scattered throughout high-lying areas in the Roggeveld Mountains. It covers an approximate area of 17982 ha $(2.2 \%$ of the total area of the Mountain Renosterveld vegetation). The high-lying terraces and plateaux consist of red brown sandy clay soils, with the rock cover varying from $20-80 \%$. The shrub cover is very high, except where a high cover of exposed rocks occurs. Compared to the high shrub cover, the cover of the grass and annual species is generally very low.

This association is differentiated by species group $\mathrm{P}$, which includes diagnostic species such as Passerina truncata and Othonna auriculifolia. Other common species present include Dicerothamnus rhinocerotis, Merxmuellerastricta and Dimorphotheca cuneata (species group Q) and Eriocephalus ericoides (species group R).

\section{DISCUSSION}

According to Rutherford and Westfall (1986), Low and Rebelo (1998) and Mucina et al. (2005) the vegetation of the subregion, as discussed in the present article, is situated predominantly in the Fynbos Biome. However, Diels (1909 in Van Wyk \& Smith 2001) concurred with Marloth (1908) that the region is floristically more closely related to the Succulent Karoo than to the Cape Floristic Region. This area was also included in the SKEP initiative and not in the CAPE (Cape Action Plan for the Environment) initiative.

The clear split between Table 1 and the table presented on the Succulent Karoo related vegetation (Van der Merwe et al. in press) reveals that most of the species in species group F (Table 1) 
are found in the general species group in the upper portion of the Succulent Karoo table, whereas most of the species in species group $Q$ (Table 1) are not found in the Succulent Karoo table. Such a finding indicates association 1's affinity with the Succulent Karoo Biome vegetation of the Escarpment Karoo, Roggeveld Karoo and Hantam Karoo, as described in Van der Merwe et al. (in press). The true Renosterveld of associations 2 and 3, as defined by species group Q (Table 1), is, however, lacking from the Succulent Karoo table and belongs to the Fynbos Biome related vegetation. This Mountain Renosterveld is probably distinct from other Renosterveld vegetation types in any case and could be studied in the future.

Grazing and cropping are the main land-uses in the Mountain Renosterveld. Sustainable land management tries to minimise the risk of veld degradation or species extinction by managing populations of plants and animals within an area to ensure that they can continue to reproduce and function normally, even after stressful conditions such as drought (Esler et al. 2006). Although damage can happen fast, recovery in the Karoo is very slow, as it depends mainly upon unpredictable rainfall events (Esler et al. 2006). Sustainable farm management planning is critical for ensuring a productive, profitable future in the region.

Inadequate farming practices, resulting from a severe lack of infrastructure, especially fencing, pose a serious threat to the vegetation. Farms in the region yield a low income as a result of the harsh environmental conditions and the unpalatable grazing caused by the dominance of Dicerothamnus rhinocerotis. Because of the low monetary value of the land and the high cost of infrastructure it is not financially viable for a farmer to invest too much in infrastructure, as the ability to recover such costs is limited. Although the farmers are generally willing to implement improved veld management and infrastructure development, their financial means hinder their doing so.

According to Low and Rebelo (1996) the degree of transformation in the Escarpment Mountain Renosterveld, which closely corresponds to the Mountain Renosterveld as described in the current article, is unknown. However, many large tracts of land cultivated in the past are still cultivated due to the higher rainfall in the region compared with that experienced in the surrounding areas of the Hantam and Tanqua Karoo.

Invasive species in the vegetation type described are predominantly annuals that were brought into the region with fodder from other parts of the world, and of which many have been naturalised over the centuries. The isolated individuals of Prosopis species present are usually limited to highly disturbed areas alongside water points and feeding areas. The unpalatable renosterbos, Dicerothamnus rhinocerotis, which dominates large sections of the Mountain Renosterveld is considered an encroacher by most farmers with its dominance being blamed on centuries of incorrect management practices in the region. Also, overgrazing is thought to have substantially reduced the grassy component in the vegetation.

The protected area network for the Mountain Renosterveld is severely under-represented. Two local municipal nature reserves, namely the Nieuwoudtville Wildflower Reserve (115 ha) and the Akkerendam Nature Reserve (230 ha), fall within the region. A natural heritage site at Banksgate, near Sutherland, protects the rare sterboom, Cliffortia arborea. The Tanqua National Park has substantially expanded during the last 3-5 years, with the latest land acquisitions including a section of Mountain Renosterveld vegetation.

In conclusion, the aims of the project described in this article were to classify and describe the various vegetation units present in the Mountain Renosterveld part of the Hantam-Tanqua-
Roggeveld subregion in terms of their species composition, environmental parameters and relationships to one another as well as to map their geographical distribution. Such an inventory of vegetation types should aid future planning, resource management and biodiversity conservation, which should encourage sustainable land use practices, reducing the negative impact on the environment.

\section{ACKNOWLEDGEMENTS}

The authors would like to thank the Critical Ecosystem Partnership Fund (CEPF) for funding the project by way of the SKEP (Succulent Karoo Ecosystem Plan/Program) initiative. The Critical Ecosystem Partnership Fund is a joint initiative of Conservation International, the Global Environmental Facility, the Government of Japan, the MacArthur Foundation and the World Bank. A fundamental goal is to ensure that civil society is engaged in biodiversity conservation. The assistance of Hennie van den Berg of Iris International in compiling the vegetation map is gratefully acknowledged. CapeNature, the Department of Tourism, Environment and Conservation (Northern Cape) and SANParks are thanked for the necessary permits and permission to conduct this research.

\section{REFERENCES}

Acocks, J.P.H. 1988. Veld types of South Africa. 3rd ed. Memoirs of the Botanical Survey of South Africa, 57: 1-146.

Agricultural Research Council 1986a. Land type map 3220 Sutherland. Pretoria: Institute for Soil, Climate and Water.

Agricultural Research Council 1986b. Land type map 3018 Loeriesfontein. Pretoria: Institute for Soil, Climate and Water.

Agricultural Research Council 1995. Land type map 3118 Calvinia. Pretoria: Institute for Soil, Climate and Water.

Agricultural Research Council 1999a. Land type map 3120 Williston. Pretoria: Institute for Soil, Climate and Water.

Agricultural Research Council 1999b. Land type map 3218 Clanwilliam. Pretoria: Institute for Soil, Climate and Water.

Agricultural Research Council 2002. Land type map 3319 Worcester. Pretoria: Institute for Soil, Climate and Water.

Agricultural Research Council 2003. Land type map 3320 Ladismith. Pretoria: Institute for Soil, Climate and Water.

CEPF, 2003. Ecosystem profile: The Succulent Karoo Hotspot Namibia and South Africa. Critical Ecosystem Partnership Fund report.

Conservation International: http://www.biodiversityhotspots. org (Accessed July 2006).

Council for Geoscience 1973. Geological map 3218 Clanwillliam. Pretoria: Council for Geoscience.

Council for Geoscience 1983. Geological map 3220 Sutherland. Pretoria: Council for Geoscience.

Council for Geoscience 1989. Geological map 3120 Williston. Pretoria: Council for Geoscience.

Council for Geoscience 1991. Geological map 3220 Ladismith. Pretoria: Council for Geoscience.

Council for Geoscience 1997. Geological map 3319 Worcester. Pretoria: Council for Geoscience.

Council for Geoscience 2001. Geological map 3118 Calvinia. Pretoria: Council for Geoscience.

Du Plessis, H.M. 1987. Land Types of the maps 2816 Alexander Bay, 2818 Warmbad, 2916 Springbok, 2918 Pofadder, 3017 Garies, 3018 Loeriesfontein. Memoirs on the Agricultural Natural Resources of South Africa, 9: 1-538.

Esler, K.J., Milton, S.J. \& Dean, W.R.J. 2006. Karoo veld ecology and management. Pretoria: Briza Publications.

Germishuizen, G. \& Meyer, N.L. (eds). 2003. Plants of southern Africa: An annotated checklist. Strelitzia, 14. Pretoria: National Botanical Institute. 
Hennekens, S.M. \& Schaminée, J.H.J. 2001. TURBOVEG, a comprehensive database management system for vegetation data. Journal of Vegetation Science, 12: 589-591.

Hill, M.O. 1979. TWINSPAN - A FORTRAN program for arranging multivariate data in an ordered two-way table by classification of the individuals and attributes. Ithaca: Ecology \& Systematics, Cornell University.

Hilton-Taylor, C. 1994. Western Cape Domain (Succulent Karoo). In Davis, S.D., Heywood, V.H. \& Hamilton, A.C. (eds), Centres of plant diversity: A guide and strategy for their conservation, 1. Cambridge: IUCN Publications Unit. pp. 201-203.

Low, A.B. \& Rebelo, A.G. 1998. Vegetation of South Africa, Lesotho and Swaziland. Pretoria: Department of Environmental Affairs and Tourism.

Marloth, R. 1908. Das Kapland, insonderheit das Reich der Kapflora, das Waldgebietund dieKaroo, pflanzengeografisch dargestellt. Wiss. Ergebn. Deutsch. Tiefsee-Exped. 'Waldivia', 1898 - 1899. 2, T. 3, Jena: Fischer.

Mucina, L., Rutherford, M.C. \& Powrie, L.W. (eds). 2005. Vegetation map of South Africa, Lesotho and Swaziland, 1 : 1000000 scale sheet maps. Pretoria: South African Biodiversity Institute.
Myers, N., Mittermeir, R.A., Mittermeir, C.G., De Fonseca, G.A.B. \& Kent, J. 2000. Biodiversity hotspots for conservation priorities. Nature, 403: 853-858.

Nelder V.J., Wilson, B.A., Thompson, E.J. \& Dillewaard, H.A. 2005. Methodology for survey and mapping of regional ecosystems and vegetation communities in Queensland. Version 3.1. Updated September 2005. Brisbane: Queensland Herbarium, Environmental Protection Agency.

Rutherford, M.C. \& Westfall, R.H. 1986. Biomes of Southern Africa. An objective characterisation. Memoirs of the Botanical Survey of South Africa, 54: 1-98.

Van der Merwe, H., Van Rooyen, M.W. \& Van Rooyen, N. In press. Vegetation of the Hantam-Tanqua-Roggeveld subregion, South Africa. Part 2. Succulent Karoo Biome related vegetation. Koedoe.

Van Wyk, A.E. \& Smith, G.F . 2001. Regions of floristic endemism in southern Africa: A review with emphasis on succulents. Pretoria: Umdaus Press.

Weather Bureau 1998. Climate of South Africa: Climate statistics up to 1990. WB 42. Pretoria: Government Printer.

Werger, M.J.A. 1974. On concepts and techniques applied in the Zürich-Montpellier method of vegetation survey. Bothalia, 11(3): 309-323. 